\title{
RANCANG BANGUN INTERNET OF THINGS DEVICE INTERFACES (IODI)
}

\author{
NUR ASMI RAHMAWATI ${ }^{1}$, TINO SUHAEBRI ${ }^{2}$ \\ A.MUHAMMAD SYAFAR ${ }^{3}$ \\ ${ }^{1,2}$ Prodi Teknik Listrik dan Instalasi, Prodi Teknik Informatika ${ }^{3}$ \\ ${ }^{1,2}$ Akademi Komunitas Industri Manufaktur Bantaeng, \\ ${ }^{3}$ Universitas Islam Negeri Alauddin Makassar \\ Email : ${ }^{1}$ nurasmi.rahmawati@gmail.com, \\ 2tinosuhaebri88@gmail.com, andi.syafar@uin-alauddin.ac.id ${ }^{3}$
}

\begin{abstract}
ABSTRAK
Internet of Things didefenisikan sebagai sebuah teknologi yang memungkinkan adanya pengendalian, komunikasi, kerja sama dengan berbagai perangkat keras, berbagai data, memvirtualisasikan segala hal nyata ke dalam bentuk internet, dan lain lain melalui jaringan internet. Perangkat dibuat dengan memanfaatkan modul wifi EP8266 dan sebuah triac dengan kapasitas arus 16A. Hasil pengujian didapatkan respon tercepat yaitu 2 detik untuk pengujian kondisi ON ke OFF dan kondisi OFF ke ON, respon terlama yaitu 10 detik untuk kondisi ON ke OFF dan 6 detik untuk kondisi OFF ke ON. Sedangkan respon waktu rata-rata yang didapatkan dari kondisi ON ke OFF adalah 5.2 detik, dan respon waktu rata-rata yang didapatkan dari kondisi OFF ke ON adalah 4.4 detik.
\end{abstract}

Kata kunci: Internet of things, IODI. ESP8266.

\section{PENDAHULUAN}

Perkembangan yang pesat dari teknologi sensor, interkoneksi, dan analisis data memunculkan gagasan untuk mengintegrasikan seluruh teknologi tersebut ke dalam berbagai bidang industri. Gagasan inilah yang menjadi revolusi industri yang berikutnya. Angka empat pada istilah Industri

4.0 merujuk pada revolusi yang ke empat. Industri 4.0 diumumkan secara apriori karena peristiwa nyatanya belum terjadi dan masih dalam bentuk gagasan.

Internet of Things merupakan sebuah teknologi yang memungkinkan adanya pengendalian, komunikasi, kerja sama dengan berbagai perangkat keras, berbagai data, memvirtualisasikan segala hal nyata ke dalam bentuk 
internet, dan lain lain melalui jaringan internet. Kedepannya perangkat IoT akan didesain dan disematkan langsung pada perangkat listrik dan elektronika sehingga perangkat listrik offline yang diciptakan dan digunakan sebelumnya menjadi tidak relevan untuk digunakan di era IoT. Karena itu kami mendesain sebuah alat yang bernama IoDi (Internet of things Device interfaces) yang dapat menghubungkan perangkat listrik offline ke jaringan internet tanpa mengubah atau mengganti rangkaian dasar perangkat tersebut sehingga secara tidak langsung akan mengubah status offline perangkat menjadi online dan dapat digolongkan menjadi perangkat IoT.

E-learning readiness tidak hanya fokus pada organisasi atau institusi, melainkan kesiapan tenaga pengajar dan siswa itu sendiri. Akaslan \& Effie (2011) secara khusus mengukur kesiapan pada segi tenaga pengajar dengan menggunakan empat komponen utama, yakni Technology, People, Content, dan Institution. Berdasarkan beberapa penelitian yang disebutkan di atas, sebagian besar pengukuran e-learning readiness terdiri dari komponen yang hampir sama. Komponen pengukuran tingkat kesiapan $e$ learning pada umumnya ditentukan berdasarkan latar belakang dan rintangan dalam pengimplementasian e-learning.

\section{METODE PENELITIAN}

Jenis penelitian ini adalah rancang bangun yang terdiri dari beberapa tahap yaitu tahap perancangan konsep, tahap pembuatan dan tahap pengujian. Rancang Bangun pada penelitian yang dilakukan terdiri dari beberapa tahap, yaitu:

1. Studi Literatur

Studi literatur dilakukan dengan mengumpulkan referensi berupa dokumen atau tulisan yang bersumber dari web, makalah atau laporan akhir. Dokumen yang dikumpulkan memiliki keterkaitan dengan penelitian yang akan dibuat yaitu tentang IoT.

2. Perancangan Rangkaian Elektronik

Blok diagram rangkaian elektronik diperlihatkan pada Gambar 2 yang 
menunjukkan beberapa bagian utama dalam sistem diantaranya:

a. ESP8266, merupakan komponen kendali yang digunakan. Komponen ini juga yang berfungsi untuk menghubungkan sistem dengan internet.

b. TRIAC, berfungsi sebagai komponen pensaklaran beban AC

c. Power Supply 5V, berfungsi untuk menyediakan tegangan sumber untuk rangkaian kendali.

d. BEBAN AC, merupakan perangkat listrik yang akan dikendalikan, dapat berupa lampu, kulkas, televisi, dan lain sebagainya. Untuk memudahkan pengendalian, beban AC ini langsung terhubung ke stop kontak.

e. Database Cloud, merupakan media penyimpanan cloud yang berisikan data pengaktifan dari perangkat Iodi.

f. Mobile Phone User, adalah perangkat yang digunakan user untuk mengendalikan Iodi dari jarak jauh.

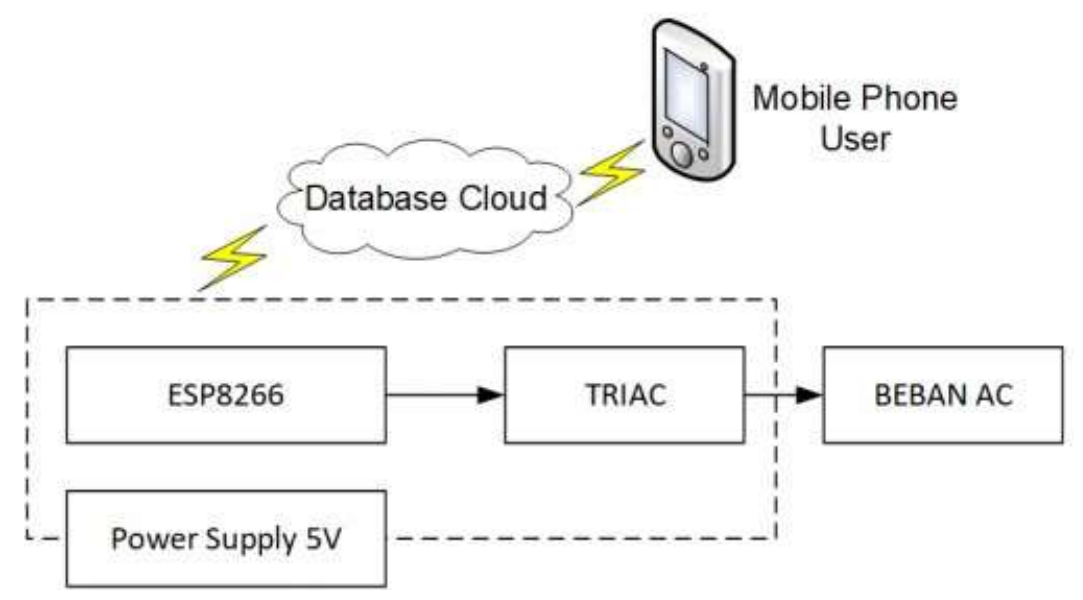

Gambar 1. Blok Diagram

Rangkaian elektronik dirancang dengan menggunakan software Altium Designer. Gambar rangkaian terlebih dahulu dibuat sesuai dengan komponen yang digunakan. Skematik rangkaian diperlihatkan pada Gambar 2 Setelah itu dilanjutkan dengan pembuatan layout PCB. Hasil rancangan layout PCB diperlihatkan pada Gambar 3. Gambar tersebut memperlihatkan rancangan PCB yang akan dibuat serta tampilan 3D dari PCB tersebut. Desain 3D ini digunakan sebagai dasar untuk pembuatan casis. 


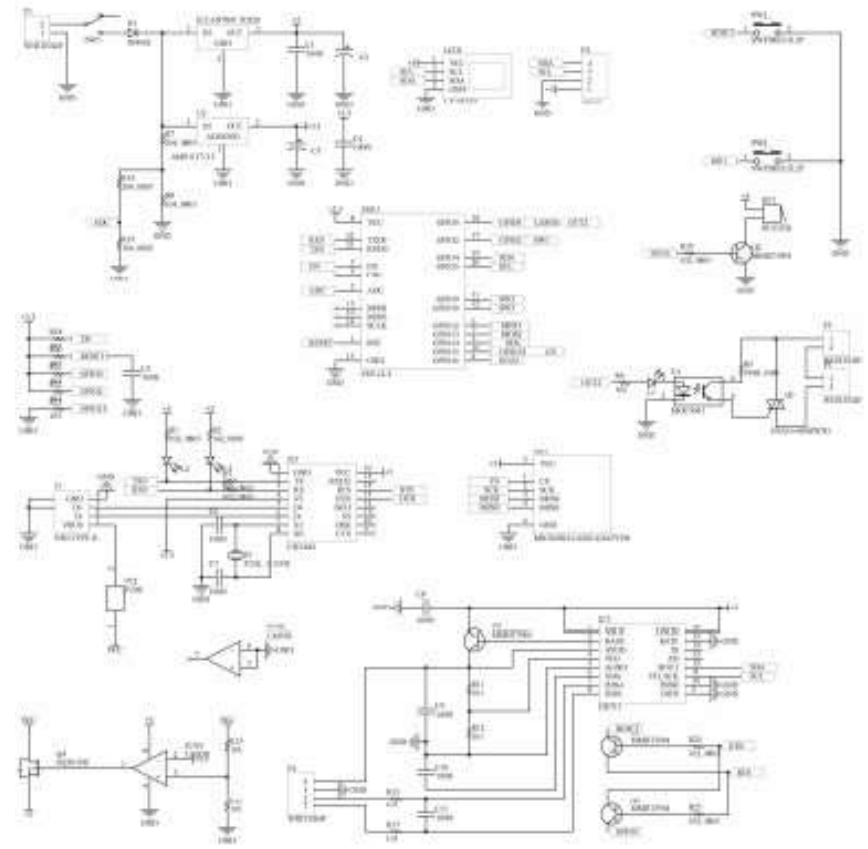

Gambar 2. Skematik Rangkaian

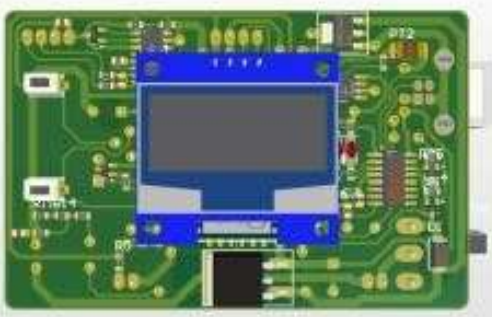

(a) Tampilan 3D tampak Atas

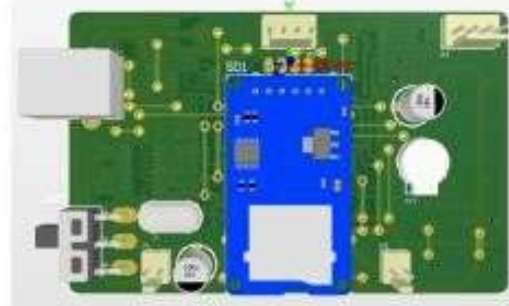

(b) Tampilan 3D tampak Bawah

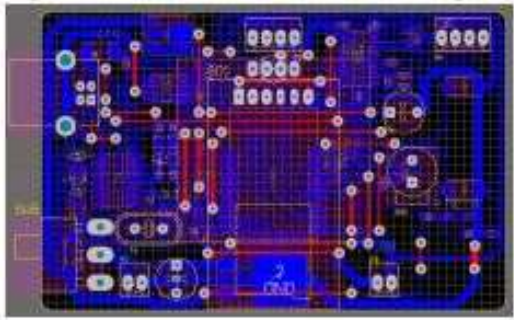

(c) Jalur double layer

Gambar 3. Desain Jalur PCB

\section{Perancangan Casis}

Casis merupakan bagian yang berfungsi sebagai dudukan rangkaian. Desain casis dibuat menggunakan software Autodesk Inventor. Rancangan casis 
diperlihatkan pada Gambar 4.

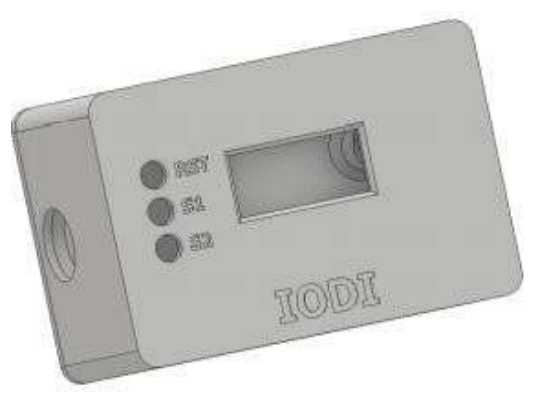

Gambar 4. Desain casis IODI

4. Pemrograman, yang terdiri dari pemrograman ESP, dan pemrograman antarmuka android. Pemrograman yang dilakukan terdiri dari pemrograman ESP8266 menggunakan aplikasi Arduino IDE, dan pemrograman Android menggunakan APP inventor.

Analisis perancangan terdiri dari pengujian rangkaian. Pengujian yang dilakukan adalah pengujian akses perangkat IODI dari perangkat android yang digunakan.

\section{HASIL DAN PEMBAHASAN}

Hasil perancangan perangkat keras berupa rangkaian IODI diperlihatkan pada Gambar 5.

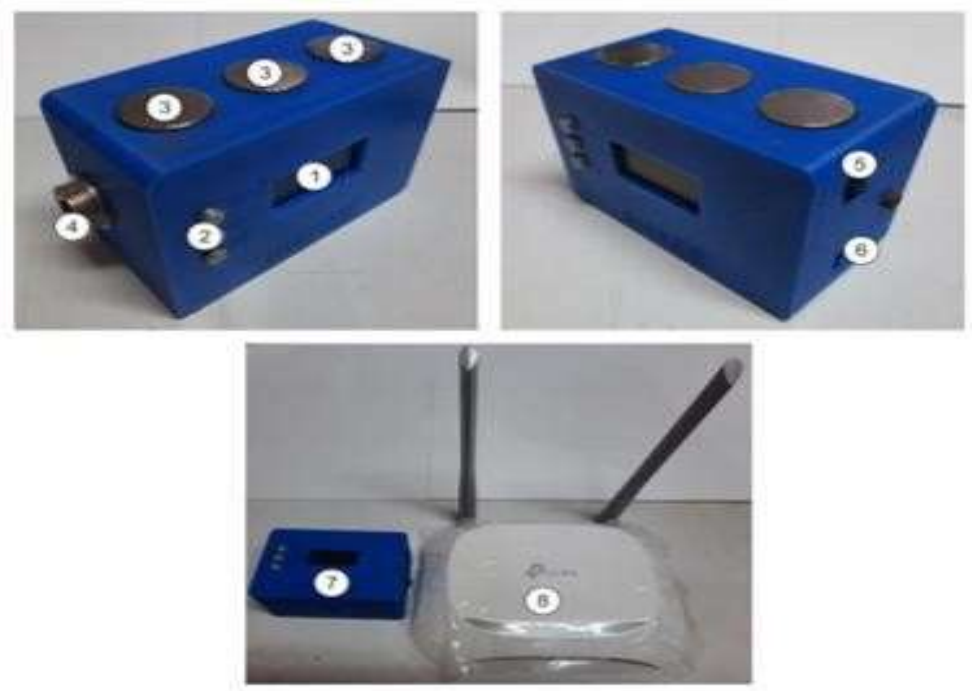

Gambar 5. Hasil Perancangan 
Keterangan:

1. Display OLED, berfungsi untuk menampilkan data yang berkaitan dengan kendali dan monitoring perangkat

2. Tombol konfigurasi, digunakan untuk melakukan pengaturan perangkat.

3. Magnet, digunakan sebagai gantungan perangkat, jika perangkat diletakkan dibawah benda logam.

4. Terminal untuk sambungan ke stop kontak.

5. sakelar ON/OFF.

6. Konektor USB, digunakan untuk mentransfer program ke perangkat.

7. Perangkat IODI.

8. Access Point.

\section{Program APP Inventor}

Hasil pembuatan program APP inventor diperlihatkan pada Gambar 6. Dari Gambar 6 tersebut dapat dilihat bahwa terdapat 2 tombol yang digunakan, yaitu tombol ON dan OFF. Sesuai dengan namanya tombol ON digunakan untuk mengaktifkan perangkat listrik, sedangkan tombol OFF digunakan untuk menonaktifkan perangkat listrik. Pemrograman blok APP inventor yang dibuat diperlihatkan pada Gambar 7. dapat diperhatikan bahwa program tidak ditulis seperti halnya pemrograman bahasa C pada ESP8266, namun dibuat dalam bentuk blok visual.

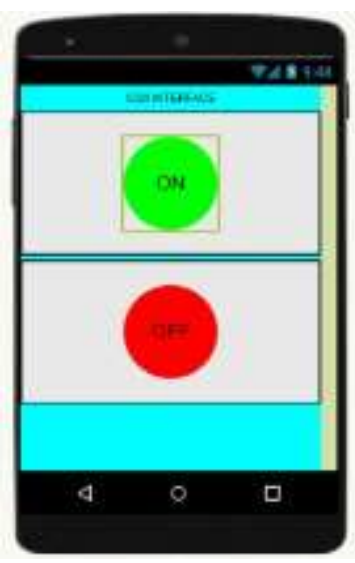

Gambar 6. Hasil Perancangan layout APP Inventor 
Ojs :http://journal.uin-alauddin.ac.id/index.php/instek/index

Email : instek@uin-alauddin.ac.id

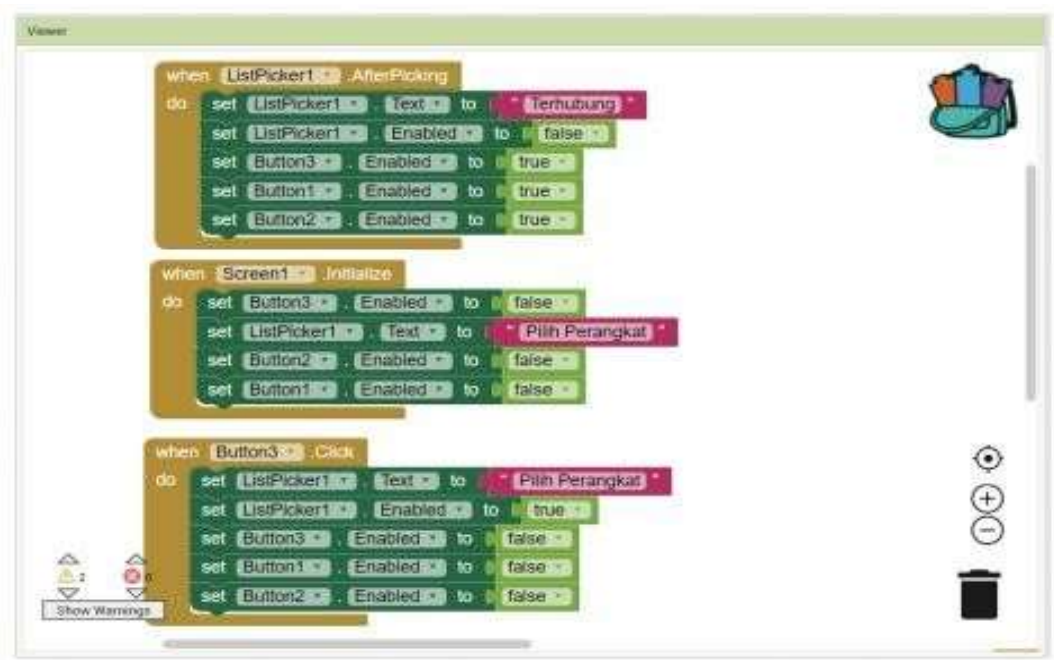

Gambar 7. Hasil Pemrograman Blok APP Inventor

Pengujian yang dilakukan adalah pengujian untuk menguji keberhasilan sistem dalam merespon perintah dari kendali perangkat android. Diagram pengujian ditunjukkan pada Gambar 8. Perangkat Iodi terhubung ke jaringan internet melalui akses point yang terhubung ke modem internet. Pada dasarnya, perangkat dapat langsung terhubung ke modem internet tanpa menggunakan aksespoint, namum pada pengujian ini access point tetap dipasang untuk meningkatkan jangkauan sinyal dari modem. Perangkat Iodi juga dihubungkan dengan sebuah lampu dan terhubungjuga ke jaringan listrik 220VAC sebagai sumber utama.

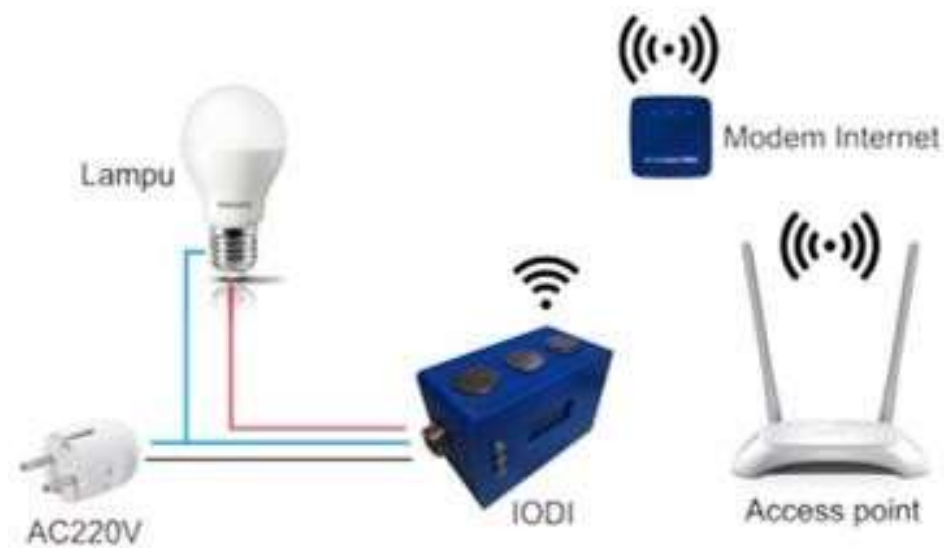

Gambar 8. Diagram pengujian sistem 
Metode pengujian yang dilakukan adalah dengan memberikan isyarat melalui aplikasi android untuk mengaktifkan lampu sebanyak 10 kali secara berulang, kemudian waktu respon dari IODI dicatat pada tabel. Hasil pengujian ditunjukkan pada Tabel 1.

Tabel 1. Hasil Pengujian Respon waktu IODI

\begin{tabular}{|c|c|c|c|}
\hline Pengujian & $\begin{array}{c}\text { Waktu ON ke OFF } \\
(\mathrm{s})\end{array}$ & $\begin{array}{c}\text { Waktu OFF ke ON } \\
(\mathrm{s})\end{array}$ & $\begin{array}{c}\text { Total Waktu } \\
(\mathrm{s})\end{array}$ \\
\hline 1 & 10 & 5 & 15 \\
\hline 2 & 5 & 2 & 7 \\
\hline 3 & 4 & 6 & 10 \\
\hline 4 & 2 & 4 & 6 \\
\hline 5 & 6 & 6 & 12 \\
\hline 6 & 7 & 2 & 7 \\
\hline 7 & 3 & 4 & 12 \\
\hline 8 & 6 & 6 & 8 \\
\hline 9 & 4 & 4 & 10 \\
\hline 10 & 5 & 5 & \\
\hline
\end{tabular}

Dari Tabel 1, respon terlama didapat pada percobaan ke 1, dengan total waktu 15 detik, sedangkan respon tercepat yaitu pada percobaan ke 4 yaitu 4 detik. Respon tercepat saat kondisi ON ke OFF didapat pada percobaan ke 4 dengan waktu 2 detik, dan respon terlama pada percobaan 1 yaitu 10 detik. Respon tercepat saat kondisi OFF ke ON didapat pada percobaan ke 2 dan 6 dengan waktu 2 detik, dan respon terlama pada percobaan 3, 5 dan 8 yaitu 6 detik.

Rata-rata waktu respon ON ke OFF dapat dihitung yaitu:

$$
\begin{aligned}
\text { Rata }- \text { rata } & =\frac{10+5+4+2+6+7+3+6+4+5}{10} \\
& =\frac{52}{10}=5.2 \text { detik }
\end{aligned}
$$

Sedangkan, rata-rata waktu respon ON ke OFF dapat dihitung yaitu:

$$
\begin{aligned}
\text { Rata }- \text { rata } & =\frac{5+2+6+4+6+2+4+6+4+5}{10} \\
& =\frac{44}{10}=4.4 \text { detik }
\end{aligned}
$$

Perbedaan respon waktu dapat terjadi dikarenakan kekuatan sinyal atau jaringan internet dari provider yang berubah ubah. Semakin lambat koneksi jaringan internet makan semakin lama respon waktu dari IODI, begitu juga sebaliknya, jika koneksi internet cepat, maka akan membuat respon IODi menjadi semakin cepat. 


\section{KESIMPULAN}

Perangkat yang dibuat dalam penelitian ini berupa sistem yang mampu membuat peralatan listrik dapat di kendalikan melalui jaringan internet. Hasil penelitian telah diuji sebanyak 10 kali percobaan dengan hasil respon tercepat yaitu 2 detik untuk kondisi ON ke OFF dan kondisi OFF ke ON, respon terlama yaitu 10 detik untuk kondisi ON ke OFF dan 6 detik untuk kondisi OFF ke ON, respon waktu rata-rata yang didapatkan dari kondisi ON ke OFF adalah 5.2 detik, dan respon waktu rata-rata yang didapatkan dari kondisi OFF ke ON adalah 4.4 detik. 


\section{DAFTAR PUSTAKA}

A. Kurniawan, "SEJARAH, CARA KERJA DAN MANFAAT INTERNET OF THINGS," vol. 8, no. 2, p. 6, 2018.

E. S. Wihidayat and D. Maryono, "Pengembangan Aplikasi Android Menggunakan Integrated Development Environment (Ide) App Inventor 2," Jurnal Geodesi Undip, vol. 4, no. 1, pp. 1-12, 2017.

F. Abdullah, "FENOMENA DIGITAL ERA REVOLUSI INDUSTRI 4.0,” Jurnal Dimensi DKV Seni Rupa dan Desain, vol. 4, p. 47, Apr. 2019.

P. A. S. Nugraha, M. Awaluddin, and B. Sasmito, "Pembuatan Aplikasi Sebaran Lokasi Wisata Kuliner Di Kota Surakarta Berbasis Android (Studi Kasus : Kota Surakarta)," Jurnal Geodesi Undip, vol. 6, no. 4, pp. 60-69, 2017.

R. P. Agrarian, A. Suprayogi, and B. D. Yuwono, "Pembuatan Aplikasi Mobile Gis Berbasis Android Untuk Informasi Pariwisata Di Kabupaten Gunung kidul," Jurnal Geodesi Undip, pp. 241-247, 2015.

S. Samsugi, A. Ardiansyah, and D. Kastutara, "Arduino dan Modul Wifi ESP8266 sebagai Media Kendali Jarak Jauh dengan antarmuka Berbasis Android," Jurnal Teknoinfo, vol. 12, p. 23, Jan. 2018.

www.dewaweb.com, "Panduan phpmyadmin untuk pemula," June 2019. Link: https://www.dewaweb.com/blog/panduan-phpmyadmin-untuk-pemula/, diakses 15 Juli 2019 